\title{
SIFAT TARIK DAN SIFAT LENTUR PADA BODY MOTOR KOMPOSIT LAMINA DENGAN PERLAKUAN ALKALI
}

\author{
Kevin Hanada ${ }^{1)}$, Sofyan Djamil' ${ }^{2)}$ dan Sobron Y. Lubis ${ }^{2)}$ \\ ${ }^{1)}$ Mahasiswa Program Studi Teknik Mesin \\ ${ }^{2)}$ Staf Pengajar Program Studi Teknik Mesin Fakultas Teknik Universitas Tarumanagara \\ e-mail: kevinh.tm@stu.untar.ac.id,sofyand@ft.untar.ac.id,sobronl@ft.untar.ac.id
}

\begin{abstract}
Composite is a combination of two or more materials that have different mechanical properties and characteristics. One of the reinforcement materials or reinforcement that is widely used is natural materials. One of Indonesia's natural materials and a very large source of bamboo is widely used in building construction as an alternative to wood because it has high flexibility and strength. To balance the strength of bamboo with high tensile strength while low flexural strength, a solution is needed to maximize the strength of bamboo by combining it with a bamboo composite system. In this study, bamboo that has been processed into woven sheets manually with plain weave type is then given a certain amount of epoxy resin and then a Tensile Strength Test is carried out using ASTM D3039 / D3039M and a flexural test using ASTM D7264 / 7264M to obtain maximum composite and flexural strength. After the test was carried out, it was continued by observing the microstructure of the specimen using SEM (Scanning Electron Microscope). The results showed the tensile test value with a value of $50 \mathrm{Mpa}$ compared to the ABS tensile strength value of $53 \mathrm{Mpa}$, the Modulus of Elasticity with a value of $0.38 \mathrm{GPa}$ compared to the ABS modulus of elasticity of $0.41 \mathrm{Gpa}$. The results of the flexural test obtained flexural strength with a value of $47.06 \mathrm{Mpa}$ compared to the value of ABS flexural strength of $49.6 \mathrm{Mpa}$, flexural modulus with a value of $0.52 \mathrm{Gpa}$ compared to the value of ABS flexural modulus of $0.55 \mathrm{Gpa}$.
\end{abstract}

Keywords: plain, epoxy, tensile, flexural.

\section{PENDAHULUAN}

Komposit merupakan kombinasi dua atau lebih material yang memiliki sifat mekanik dan karakteristik berbeda. Salah satu material penguat atau reinforcement yang banyak digunakan adalah material alam [1]. Pada saat ini, material alam merupakan pilihan yang baik dalam berbagai industri seperti otomotif, penerbangan, migas (minyak dan gas) dan lain-lain, karena memiliki kelebihan seperti ramah lingkungan, biaya pembuatan dan bahan yang lebih murah dan ketersediaan yang berlimpah untuk jangka panjang.

Salah satu material alam yang banyak Indonesia dan sumber yang sangat banyak yaitu bambu, banyak digunakan dalam konstruksi bangunan sebagai alternatif pengganti kayu karena memiliki sifat kelenturan dan kekuatannya yang tinggi. Secara umum industri saat ini sering menggunakan logam atau polimer dan komposit alam sebagai komponen-komponen konstruksi, yang memiliki keunggulan masing-masing [2].

Dalam perkembangan, bambu dapat digunakan sebagai struktur pengganti kayu maupun baja, contoh penggunaan bambu sebagai rangka kuda-kuda dan rangka jembatan [4]. Pada penelitian-penelitian yang terdahulu penggunaan bambu untuk struktur rangka masih berupa bambu model asli dari alam yaitu berbentuk silinder, akan tetapi dalam penyambungan memang mengalami kendala untuk mengimbangi kekuatan bambu itu sendiri. Untuk mengimbangi kekuatan bambu dengan kekuatan tarik yang tinggi sedangkan kekuatan lentur rendah, perlu dicari solusi agar bisa memaksimalkan kekuatan bambu dengan mengkombinasikan dua atau lebih dari komponen, sehingga menjadi komposit bambu. Penelitian ini, diharapkan meningkatkan nilai guna bambu sebagai reinforcement, sehingga dapat digunakan sebagai bagian dari komposit alam, dan industri-industri dapat memanfaatkan bambu semaksimal mungkin [4]. Pada penelitian ini, bambu yang sudah diolah menjadi lembaran-lembaran akan dianyam secara manual dengan tipe plain weave lalu diberikan resin epoxy dengan jumlah tertentu dan pada akhirnya akan dilakukan uji tarik (tension test) dan uji lentur (flexural test) untuk mendapatkan nilai kekuatan tarik dan kekuatan lentur maksimum komposit bambu tersebut serta akan disajikan dalam bentuk kurva. 


\section{METODE PENELITIAN}

Metodologi ini dilakukan dalam beberapa tahap: persiapan bahan baku, pembuatan strip bambu secara manual, pembuatan spesimen dan pengujian menurut standar ASTM D7264/7264M untuk tensile test dan ASTM D3039/D3039M untuk flexural test, analisa hasil pengujian dan pengambilan kesimpulan seperti yang dapat dilihat pada diagram alir di Gambar 1. Metode yang dilakukan dijelaskan dalam diagram alir (flowchart) di bawah ini:

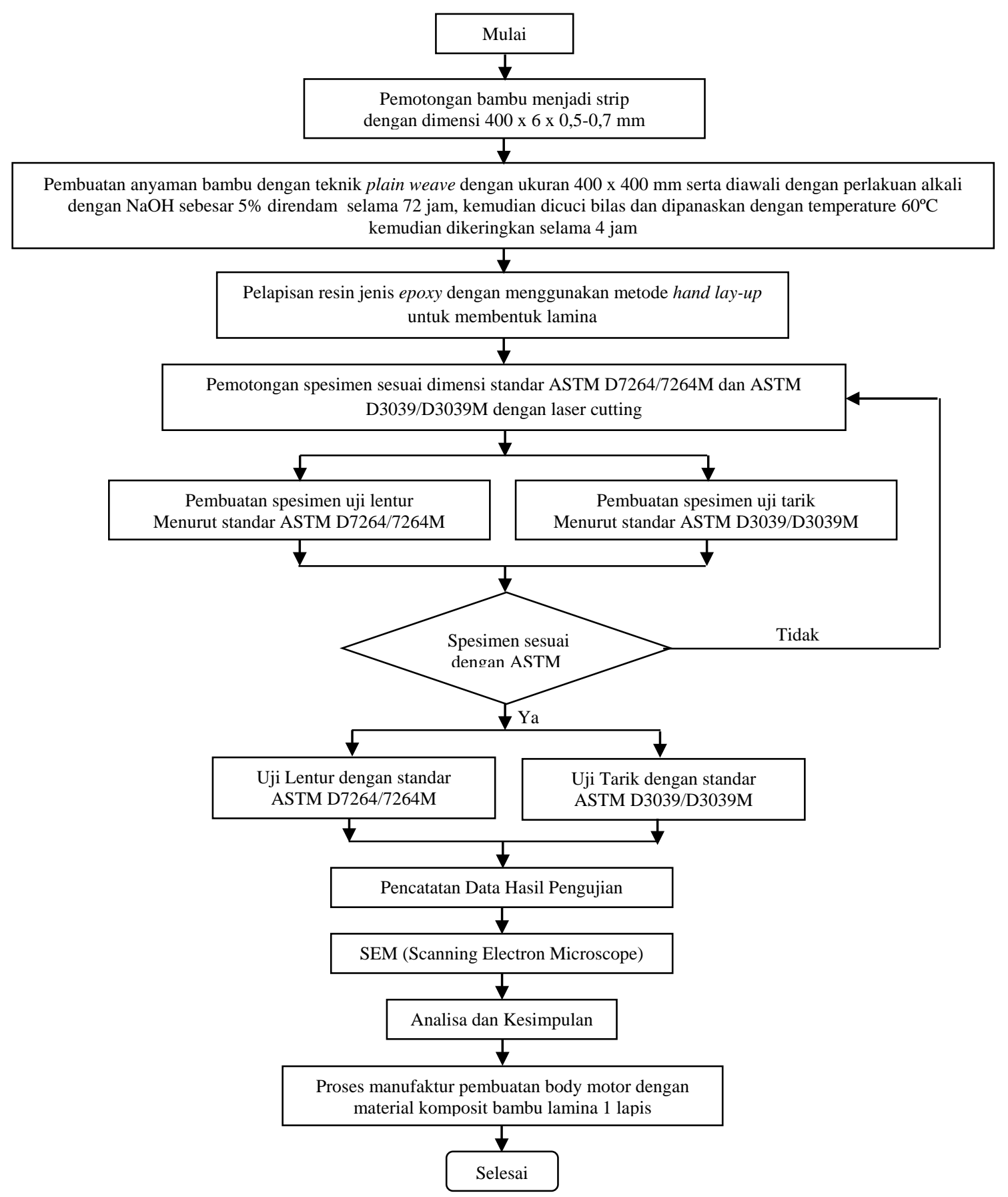

Gambar 1. Diagram alir proses penelitian

\section{Tahapan penelitian}

1. Tahapan bahan baku bambu

a. Bambu diambil dari desa Mekarsari, kelurahan Negrasi, Kecamatan Karawaci, Kota Tangerang yang berjenis bambu apus (gigantochloa apus) berumur 3-4 tahun. 
b. Bambu dipotong dengan pisau secara manual hingga berukuran strip dengan tebal 0,5-0,7 $\mathrm{mm}$ dan lebar $6 \mathrm{~mm}$.

\section{Proses Perlakuan Alkali}

Perlakuan alkali dilakukan untuk memisahkan lignin dan kontaminan yang terkandung di dalam strip bambu untuk menghilangkan lignin sehingga dapat meningkatkan adhesi antarmuka reinforcement dan matrix. Proses perendaman dengan larutan $\mathrm{NaOH} 5 \%$ selama 72 jam dan dipanaskan di oven pada temperatur $60^{\circ} \mathrm{C}$. Strip bambu dikeringkan dalam temperatur ruang selama 4 jam.
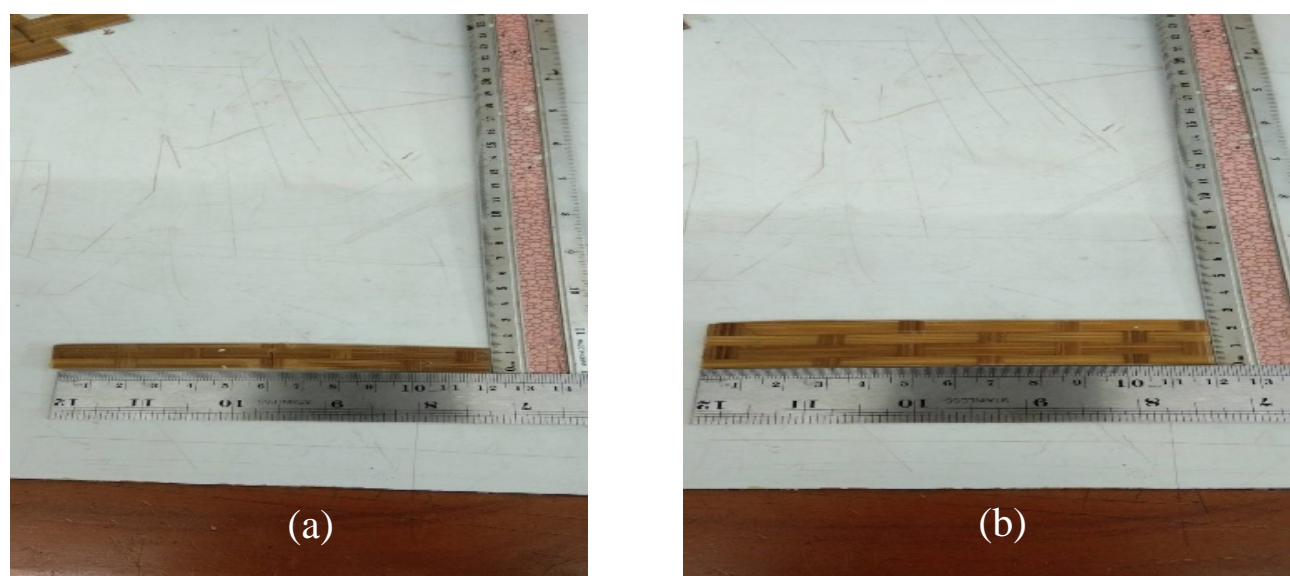

Gambar 2. Spesimen (a) Uji tarik dengan standar pengujian ASTM D3039/D3039M dan

(b) Uji lentur dengan standar pengujian ASTM D7264/D7264

3. Pengujian Tarik

Pengujian tarik menggunakan spesimen uji dengan dimensi mengikuti standar ASTM D3039/D3039M. Pengujian ini dapat dibagi menjadi tahapan sebagai berikut.

1. Pengukuran lebar dan tebal spesimen uji dengan menggunakan jangka sorong pada tiga titik yang berbeda.

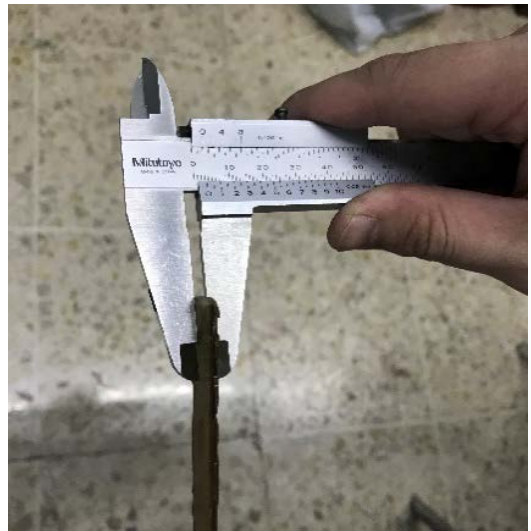

(a)

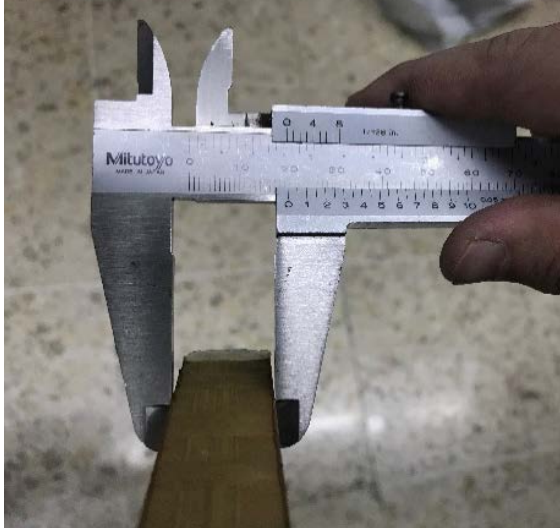

(b)

Gambar 3. Pengukuran (a) Lebar dan (b) Tebal spesimen uji tarik

2. Pemasangan fixture pada universal testing machine untuk digunakan sebagai pencekam spesimen.

3. Peletakkan spesimen secara vertikal.

4. Pengujian dilakukan dengan menekan tombol reset-dpm 2-ld 2-start pada digitalized control untuk membuat nilai displacement dan load menjadi nol. Pengujian dilakukan dengan pemberian load maksimal sebesar 99,99 kN. 
5. Pengujian dimulai dengan menekan tombol down pada universal testing machine dan nilai load yang sedang diberikan pada spesimen uji dapat dilihat pada layar digitalized control. Nilai load yang digunakan dalam perhitungan adalah nilai load maksimal yang terbaca pada digitalized control.

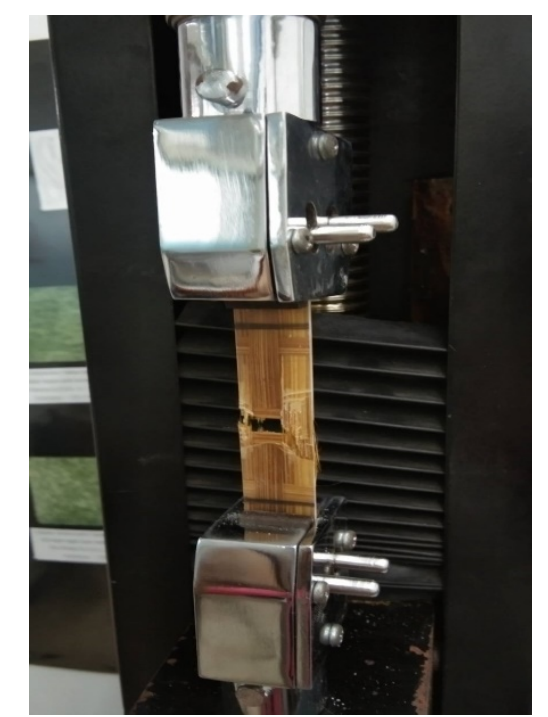

Gambar 4. Proses pengujian tarik

6. Pengujian dilakukan kembali dengan tahapan yang sama sebanyak lima kali untuk mendapatkan data yang diperlukan.

\section{Pengujian lentur}

Pengujian lentur menggunakan spesimen uji dengan dimensi mengikuti standar ASTM D7264/D7264M - 07. Pengujian ini dapat dibagi menjadi tahapan sebagai berikut.

1. Pengukuran lebar dan tebal spesimen uji dengan menggunakan jangka sorong pada tiga titik yang berbeda.

Pemasangan span dan juri pelengkung pada universal testing machine untuk digunakan sebagai pemberi load dan tumpuan spesimen uji.

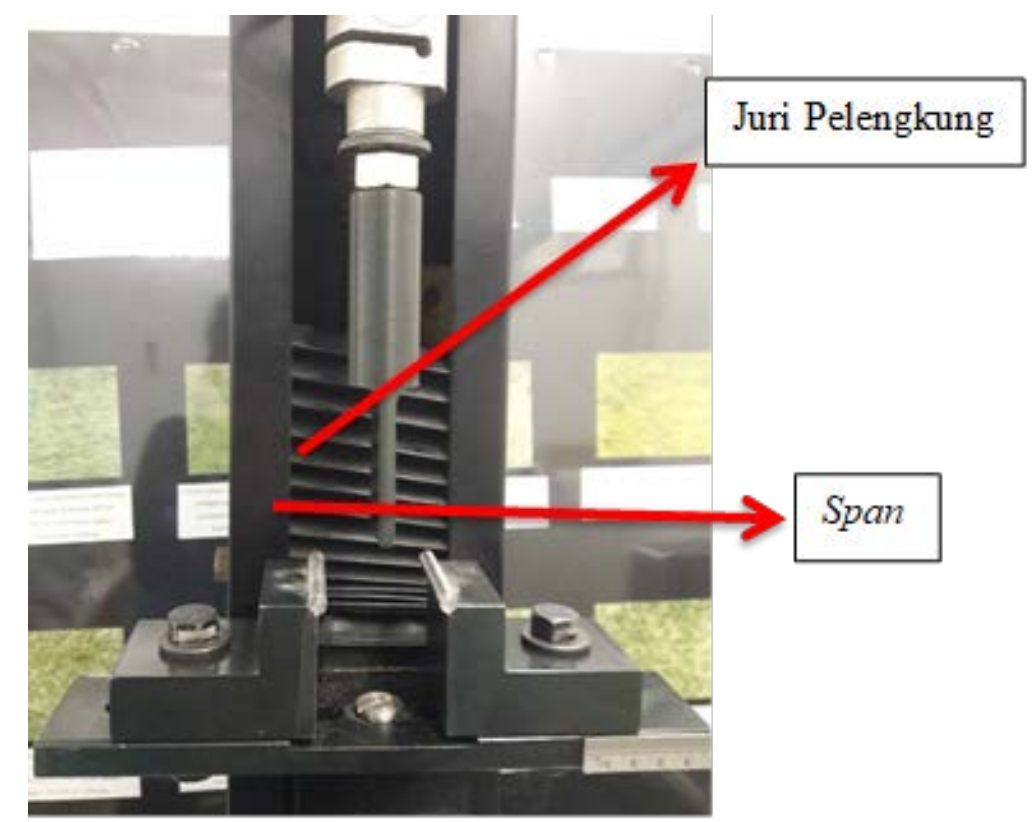

Gambar 5. Juri pelengkung dan span 
2. Peletakkan spesimen secara horizontal pada span dengan jarak span sesuai dengan standar pengujian dan diposisikan tepat terhadap juri pelengkung.

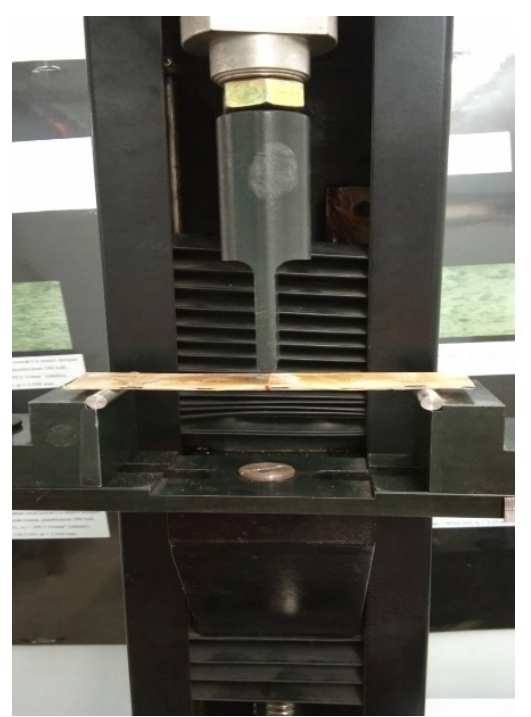

Gambar 6. Penempatan spesimen uji lentur

3. Pengujian dilakukan dengan menekan tombol reset-dpm 2-ld 2-start pada digitalized control untuk membuat nilai displacement dan load menjadi nol. Pengujian dilakukan dengan pemberian load maksimal sebesar $99.99 \mathrm{kN}$.

Pengujian dimulai dengan menekan tombol up pada universal testing machine dan nilai load yang sedang diberikan pada spesimen uji dapat dilihat pada layar

\section{HASIL DAN PEMBAHASAN}

Hasil pengujian spesimen dapat dilihat pada Gambar 7 untuk uji tensile dan Gambar 8 untuk uji flexural.

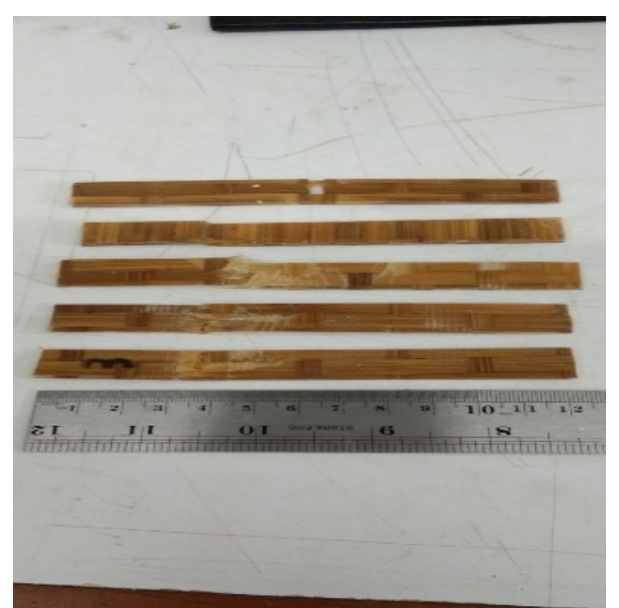

Gambar 7. Hasil pengujian tensile spesimen standar pengujian ASTM D3039/D3039M

Hasil pengujian tarik dapat dihitung:

$$
\sigma=\frac{F}{A_{0}}
$$


$\varepsilon=\frac{\mathrm{l}_{\mathrm{i}}-\mathrm{l}_{0}}{\mathrm{l}_{0}}$

$E=\frac{\sigma}{\varepsilon}$

dengan:

$$
\begin{aligned}
& \mathrm{F}=\text { Gaya Tarik }(\mathrm{kN}) \\
& \mathrm{A}_{0}=\text { Luas Penampang }\left(\mathrm{mm}^{2}\right) \\
& \mathrm{l}_{\mathrm{i}}=\text { Panjang Akhir }(\mathrm{mm}) \\
& \mathrm{l}_{0}=\text { Panjang Awal }(\mathrm{mm})
\end{aligned}
$$

\begin{tabular}{|c|c|c|c|c|}
\hline Spesimen & $\begin{array}{c}F \\
(\mathbf{k N})\end{array}$ & $\begin{array}{c}\varepsilon \\
(\%)\end{array}$ & $\begin{array}{c}\sigma_{\mathrm{t}} \\
(\mathrm{MPa})\end{array}$ & $\begin{array}{c}E_{t} \\
(\mathrm{GPa})\end{array}$ \\
\hline 1 & 1,14 & 0,49 & 50,00 & 0,25 \\
\hline 2 & 1,18 & 0,51 & 41.40 & 0.21 \\
\hline 3 & 0,92 & 0,4 & 40,75 & 0.16 \\
\hline 4 & 1,78 & 0,76 & 49.96 & 0.38 \\
\hline 5 & 1,50 & 0,64 & 42,70 & 0.27 \\
\hline \multicolumn{3}{|c|}{ Max } & 50,00 & 0.38 \\
\hline \multicolumn{3}{|c|}{ Min } & 40,75 & 0.16 \\
\hline \multicolumn{3}{|c|}{ Rata-rata } & 44,97 & 0.34 \\
\hline \multicolumn{3}{|c|}{ Standar deviasi } & 4,62 & 0.01 \\
\hline
\end{tabular}

Tabel 1. Hasil pengujian tensile spesimen uji

\begin{tabular}{|c|c|c|c|c|}
\hline Pengujian & $\begin{array}{c}\mathbf{F} \\
(\mathbf{k N})\end{array}$ & $\begin{array}{c}\varepsilon \\
(\%)\end{array}$ & $\begin{array}{c}\sigma_{\mathrm{f}} \\
(\mathrm{MPa})\end{array}$ & $\begin{array}{c}E_{f} \\
(\mathrm{GPa})\end{array}$ \\
\hline 1 & 0,14 & 0,084 & 41,50 & 0,49 \\
\hline 2 & 0,14 & 0,083 & 41,67 & 0,51 \\
\hline 3 & 0,16 & 0,090 & 47,06 & 0,52 \\
\hline 4 & 0,15 & 0,089 & 44,64 & 0,50 \\
\hline 5 & 0,13 & 0,087 & 37,79 & 0,43 \\
\hline \multicolumn{3}{|c|}{ Max } & 47,06 & 0,52 \\
\hline \multicolumn{3}{|c|}{ Min } & 37,79 & 0,43 \\
\hline \multicolumn{3}{|c|}{ Rata-rata } & 42,53 & 0,49 \\
\hline \multicolumn{3}{|c|}{ Standar deviasi } & 4,63 & 0,04 \\
\hline
\end{tabular}

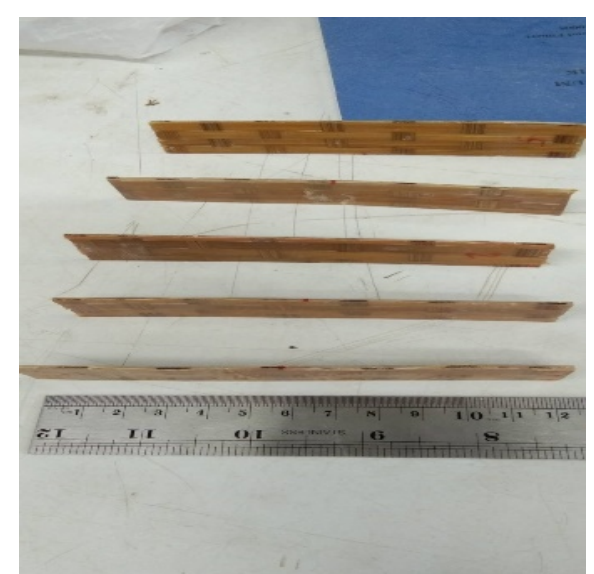

Gambar 8. Hasil pengujian flexural spesimen standar pengujian ASTM D7264/D7264M

Tabel 2. Hasil pengujian flexural spesimen uji 
Hasil pengujian flexural dapat dihitung:

$\sigma=\frac{3 P L}{2 b h^{2}}$

$\varepsilon=\frac{6 \delta h}{L^{2}}$

$\mathrm{E}=\frac{\sigma}{\varepsilon}$

dengan:

$$
\begin{aligned}
& \sigma=\text { Tegangan }(\mathrm{MPa}) \\
& \mathrm{P}=\text { Gaya Tekan }(\mathrm{kN}) \\
& \mathrm{L}=\text { Panjang }(\mathrm{mm}) \\
& \mathrm{b}=\text { Lebar Spesimen }(\mathrm{mm}) \\
& \mathrm{h}=\text { Tebal Spesimen }(\mathrm{mm})
\end{aligned}
$$

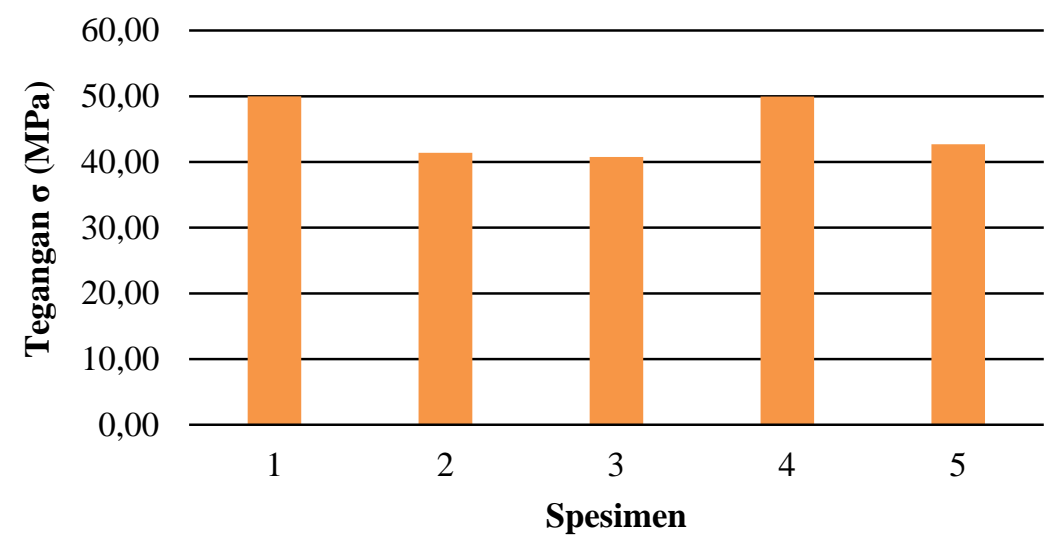

Gambar 5. Grafik nilai tensile strength spesimen uji

Spesimen 3 menunjukan nilai tegangan terendah yang disebabkan oleh adanya gelembung udara yang terperangkap di dalam komposit hal ini mengakibatkan mudahnya komposit mengalami patah/ fracture

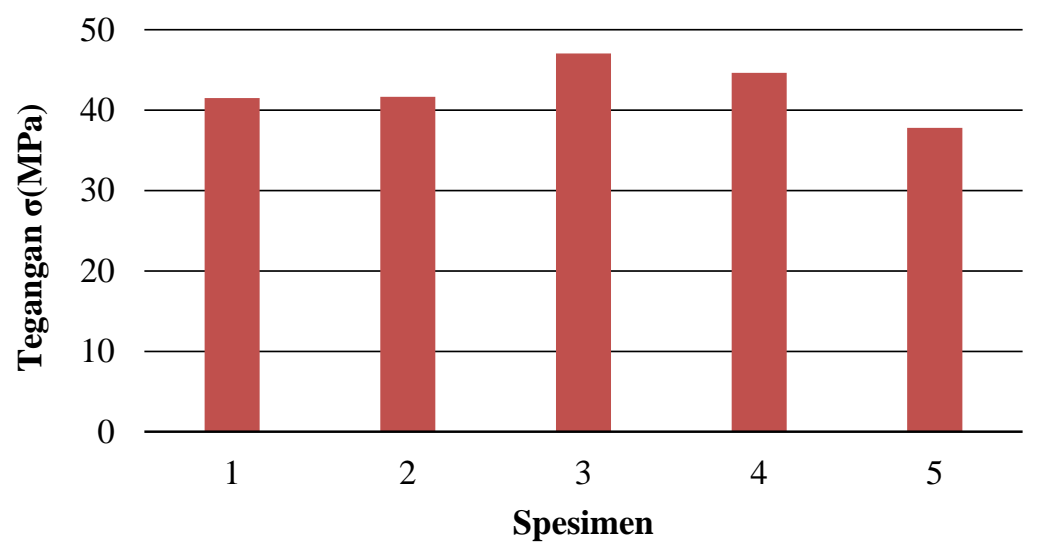

Gambar 6. Grafik nilai flexural strength spesimen uji

Spesimen 1 menunjukan nilai tegangan terendah yang disebabkan oleh adanya gelembung udara yang terperangkap di dalam komposit hal ini mengakibatkan mudahnya komposit mengalami patah/fracture. 
Setelah dilakukan pengujian, perhitungan data dan analisis hasil, data berupa tensile strength dan flexural strength spesimen uji dibandingkan dengan spesimen uji ABS (Acrylonitrile Butadiene Styrene) yang pada umumnya digunakan untuk salah satu aplikasi body motor. Berikut hasil komparasi kekuatan masing-masing material:

Tabel 3. Perbandingan sifat mekanis material body motor ABS dan material komposit uji

\begin{tabular}{ccccc}
\hline Spesimen & $\begin{array}{c}\text { Tensile } \\
\text { Strength }\end{array}$ & $\begin{array}{c}\text { Flexural } \\
\text { Strength }\end{array}$ & $\begin{array}{c}\text { Modulus } \\
\text { Elastisitas }\end{array}$ & $\begin{array}{c}\text { Modulus } \\
\text { Flexural }\end{array}$ \\
\hline $\begin{array}{c}\text { Komposit } \\
\text { bambu lamina }\end{array}$ & $50 \mathrm{MPa}$ & $47,06 \mathrm{MPa}$ & $0,38 \mathrm{GPa}$ & $0,52 \mathrm{GPa}$ \\
\hline ABS & $53 \mathrm{MPa}$ & $49,6 \mathrm{MPa}$ & $0,41 \mathrm{GPa}$ & $0,55 \mathrm{GPa}$ \\
\hline
\end{tabular}

Berdasarkan Tabel 3, dapat dilihat bahwa nilai modulus elastisitas dan flexural komposit uji memiliki nilai yang setara dengan material ABS. Hal tersebut disebabkan karena komposit terdiri dari matrix berupa epoxy yang bersifat getas dan reinforcement berupa serat bambu. Perpaduan antara epoxy yang bersifat getas dan serat bambu menghasilkan komposit yang mampu menahan beban flexural dan tensile yang tinggi. Namun material ABS merupakan jenis polimer thermoplastic yang dapat didaur ulang dan bersifat elastis, maka material ABS memiliki keunggulan berupa sustainability yang lebih meyakinkan karena ketika mendapatkan beban berlebih, body motor yang menggunakan material ABS mengalami deformasi yang dapat diperbaiki tapi akan mengalami fatigue dalam jangka waktu yang lama.

\section{Pengamatan hasil pengujian dengan SEM (Scanning Electron Microscope)}

Hasil pengujian diamati dengan menggunakan SEM (Scanning Electron Microscope) dengan perbesaran 50x untuk menganalisa bentuk patahan yang terjadi pada spesimen.

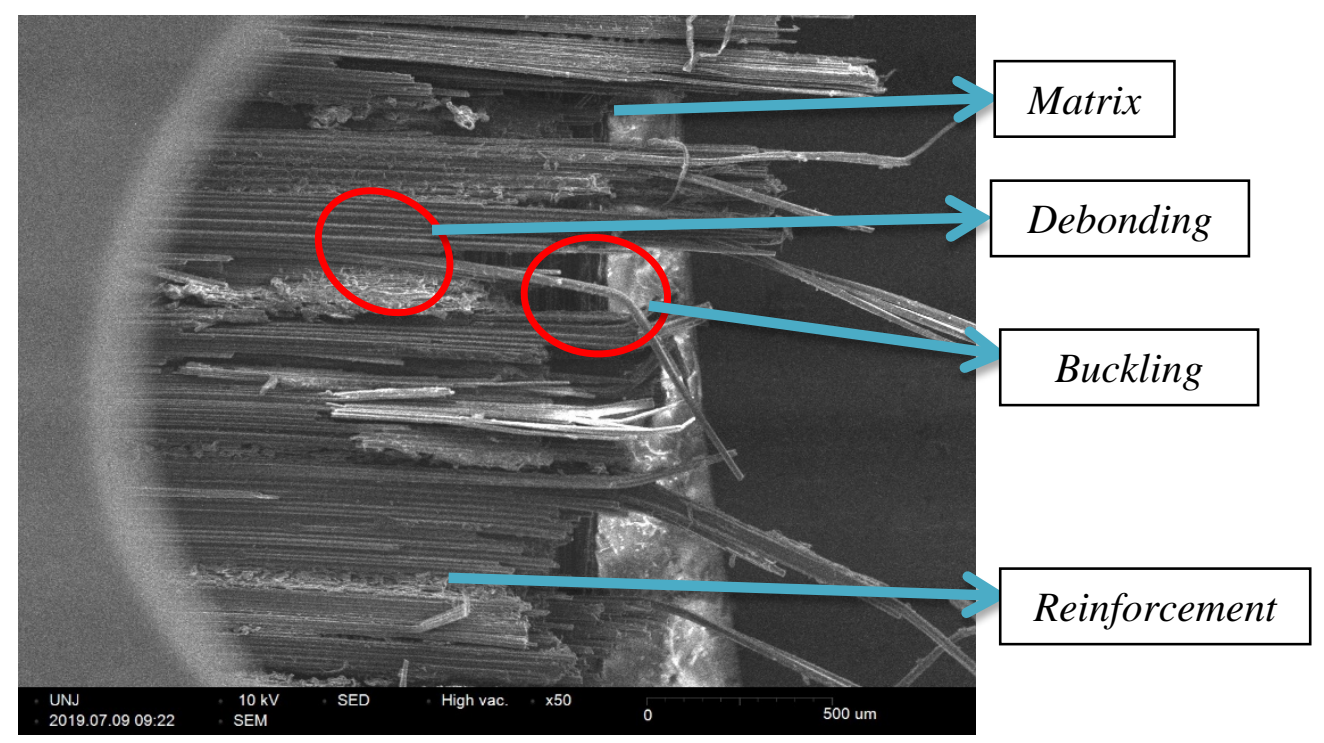

Gambar 7. Bentuk patahan spesimen uji tarik

Berdasarkan Gambar 7 dan Gambar 8, dapat dilihat bahwa penyebab patahnya spesimen uji adalah fenomena debonding, merupakan mekanisme lepasnya ikatan interface antar material penyusun komposit saat terjadi pembebanan. Komposit terdiri dari matrix dan reinforcement yang dikombinasikan menjadi sebuah kesatuan. Matrix berfungsi untuk menyalurkan beban yang diterima ke reinforcement, maka ketika beban yang diberikan melebihi beban yang mampu diterima komposit, mengalami failure. Spesimen uji yang mengalami break, terjadi fase debonding, 
disebabkan ikatan interface yang lemah antara matrix berupa resin epoxy dan reinforcement berupa anyaman bambu.

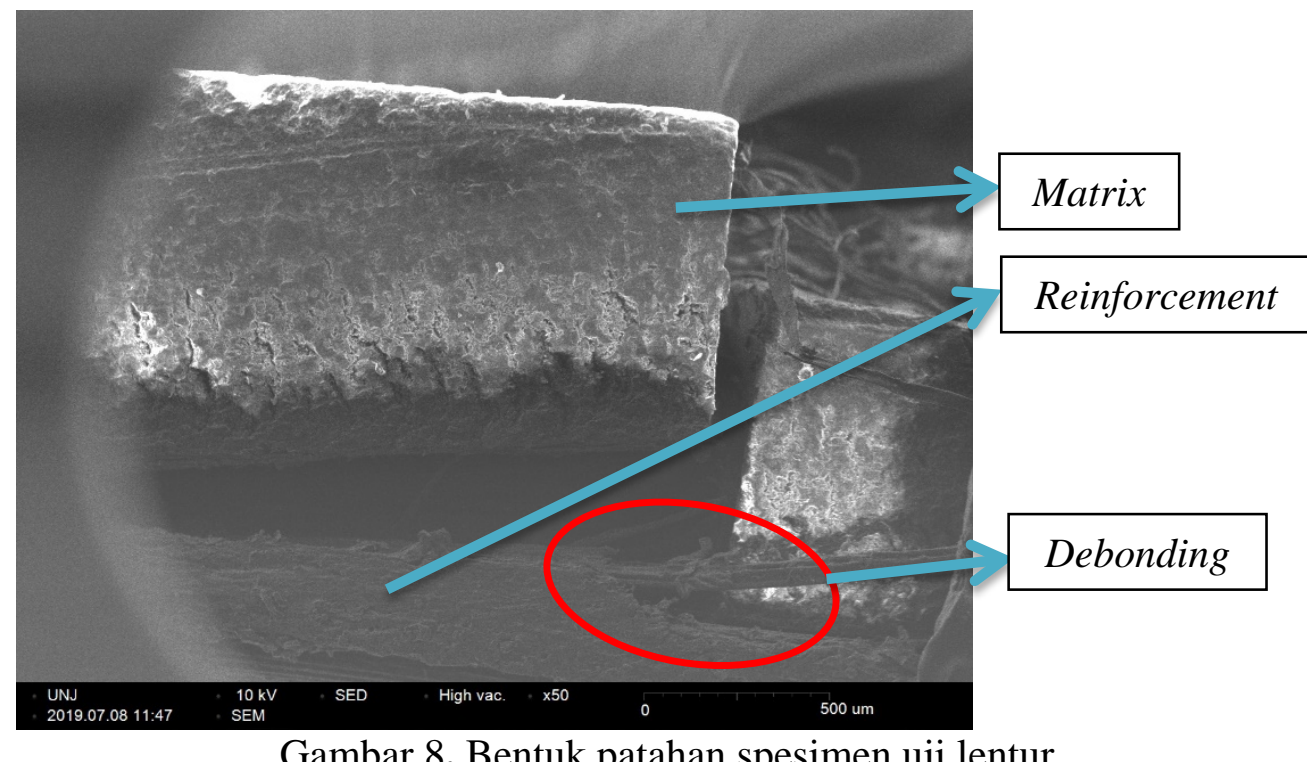

\section{SIMPULAN}

Setelah melakukan pengujian dan analisis terhadap komposit bambu lamina, dapat diambil disimpulkan.

1. Dari pengujian lentur pada komposit, didapatkan nilai tegangan lentur maksimum 47,06 $\mathrm{MPa}$ dan modulus flexural sebesar 0,52 GPa. Sedangkan untuk material ABS tegangan lentur maksimum 49,06 MPa dan modulus flexural sebesar 0,55 Pa,

2. Hasil pengujian tarik pada komposit, didapatkan nilai tegangan tarik maksimum 50,00 MPa dan modulus elastisitas sebesar 0,38 GPa. Dan untuk material ABS nilai tegangan tarik maksimum 53,00 MPa dan modulus elastisitas sebesar 0,41 Gpa.

\section{DAFTAR PUSTAKA}

[1] Mazumdar, Sanjay K., 2002. Composites Manufacturing: Materials, Product, and Process Engineering. CRC Press LLC.Boca Raton, Florida: USA.

[2] Hirmawan, Buyung. 2010. Sifat Mekanik Komposit Serat Bambu Akibat Pengaruh Musim Hujan Dengan/Tanpa Pelapisan.Jurusan Teknik Fisika Institut Teknologi Surabaya, Jawa Timur.

[3] Verma, C.S. and Chariar, V.M..2012. Development of Layered Laminae Bamboo Composite and Their Mechanical Properties. AICTE Chanderlok Building, Janpath, New Delhi: India.

[4] Kresnarini, Hesti Indah. 2011. Menggali Peluang Ekspor untuk Produk dari Bambu.Kementerian Perdagangan Republik Indonesia: Jakarta.

[5] ASTM International. D7264: Standard Test Method for Flexural Properties of Polymer Matrix Composite Materials. West Conshohocken: USA. 2007.

[6] ASTM International. D3039: Standard Test Method for Tensile Properties of Polymer Matrix Composite Materials. West Conshohocken: USA. 2007.

[7] Putra, D. R., \& Sosiati, H. (2017). Karakterisasi Kuat Tarik Komposit Laminat Hibrida Kenaf/E-Glass Yang Difabrikasi Dengan Matriks Polypropylene. JMPM (Jurnal Material dan Proses Manufaktur), 1(1), 41-45.

[8] Ghozali, M. Y. G., Budiyantoro, C., \& Sosiati, H. (2017). Karakterisasi Kuat Tarik Komposit Laminat Hibrid Kenaf-E-Glass/Polyethylene (Pe). JMPM (Jurnal Material dan Proses Manufaktur), 1(1), 31-35. 
[9] Djamil, S., Lubis, S., \& Pospos, C. C. (2018). Sifat mekanik pada komposit lamina menggunakan matriks kayu mahoni dan reinforcement bambu. Jurnal Teknik Mesin Indonesia, 12(2), 83-89.

[10] Purna Irawan, A., \& Sukania, I. W. (2018). Kekuatan Tekan Material Spoiler Mobil Berbasis Komposit Rotan Epoksi. Jurnal Imiah Teknik Mesin POROS, 16(1), 64-68.

[11] Lasarus, R. (2018, December). Analisis Sifat Mekanik Serat Kulit Kayu Khombuow Dan Serbuk Bambu Dengan Metode Uji Tarik. In Neutrino Vol. 1, No. 2, pp. 13-17. 